\title{
BIBLIOGRAPHY OF REPORTS FROM THE VOLCANO HAZARDS PROGRAM WATER RESOURCES DIVISION, 1980-1994
}

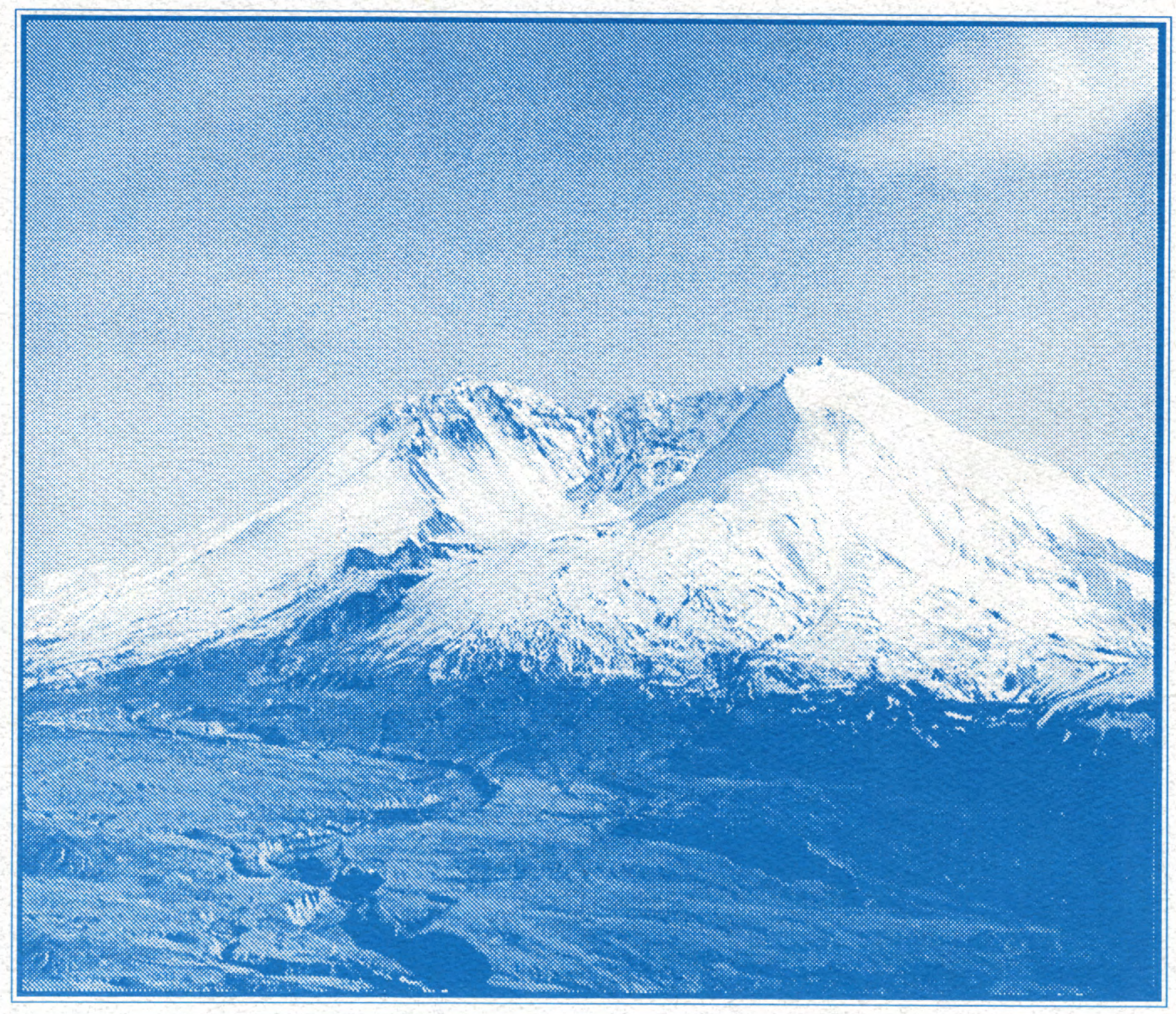

U.S. DEPARTMENT OF THE INTERIOR

U.S. Geological Survey

Open-File Report 95-131

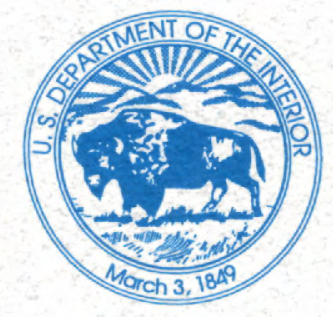





\section{BIBLIOGRAPHY OF REPORTS FROM THE \\ VOLCANO HAZARDS PROGRAM, \\ WATER RESOURCES DIVISION, 1980-1994}

\section{U.S. Geological Survey}

Open-File Report 95-131

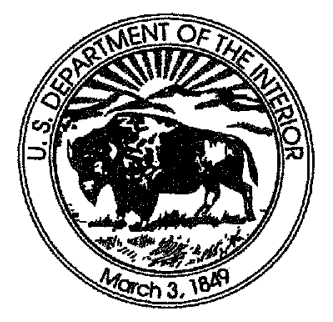

Vancouver, Washington

1995 


\title{
DEPARTMENT OF THE INTERIOR \\ BRUCE BABBITT, Secretary
}

\section{U.S. GEOLOGICAL SURVEY}

\author{
Gordon P. Eaton, Director
}

For additional information write to:

\section{U.S. Geological Survey}

Cascades Volcano Observatory

5400 MacArthur Boulevard

Vancouver, WA 98661
Copies of this report can be purchased from:

U.S. Geological Survey Earth Science Information Center Open-File Reports Section Box 25286, MS 517

Denver Federal Center

Denver, CO 80225 


\section{CONTENTS}

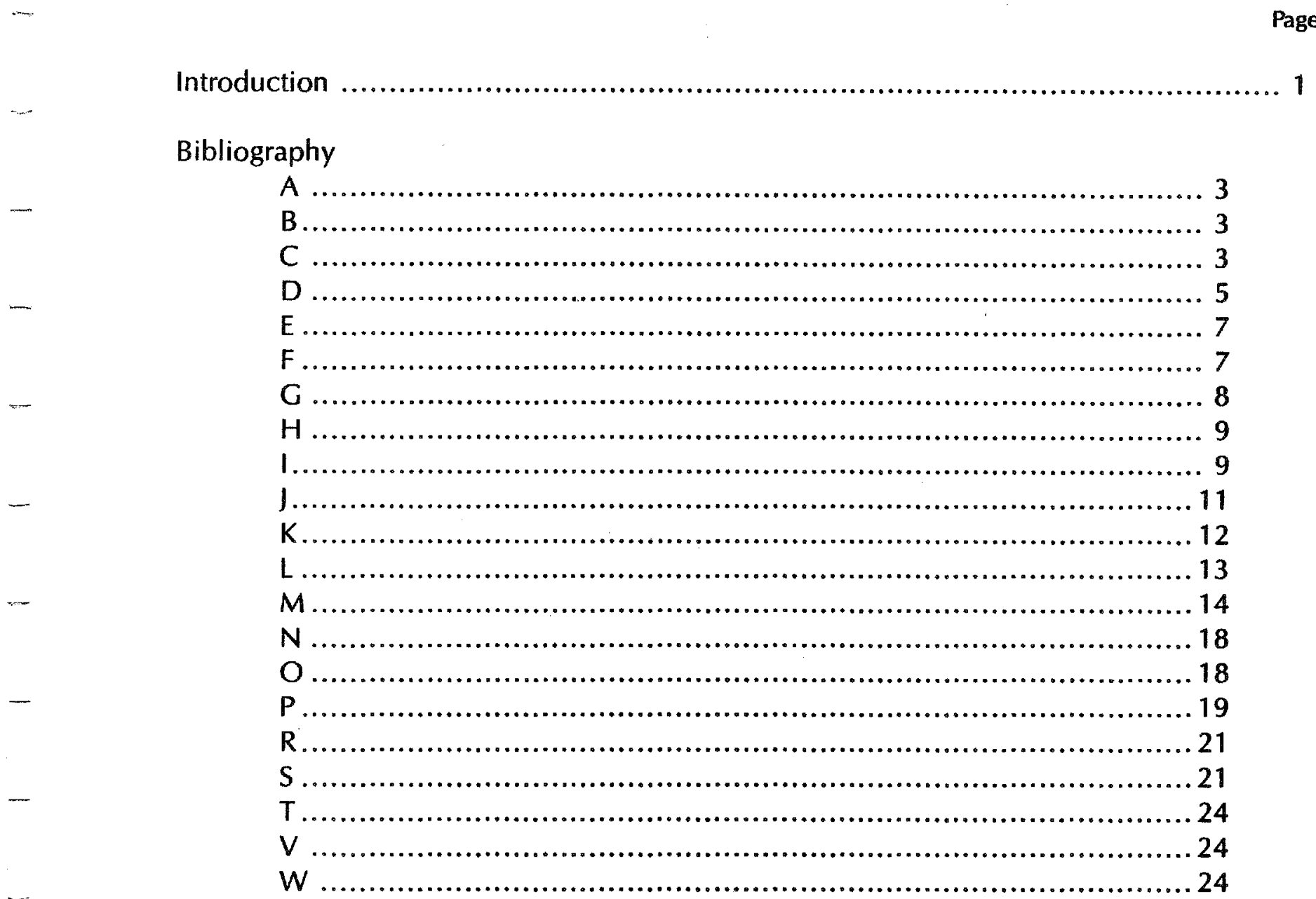





\section{BIBLIOGRAPHY OF REPORTS FROM THE VOLCANO HAZARDS PROGRAM WATER RESOURCES DIVISION, 1980-1994}

\section{Introduction}

This report consists of a bibliography of articles and abstracts that pertain to hydrologic investigations of volcanoes and processes that occur at volcanoes. References are included to work in Alaska, Hawaii, the western United States, and several international locations. The bibliography is alphabetical by author.

The Water Resources Division began investigations of the hydrologic aspects of active volcanism in 1980 following the catastrophic eruption of Mount St. Helens, Washington. Investigations continue today (1995). This bibliography revises and updates an earlier bibliography that includes publications by Geologic Division as well as Water Resources Division: Bargar, K.E., 1990, Publications of the Volcano Hazards Program, U.S. Geological Survey, 1986-1989, 77p. Copies of abstracts or reports listed in this current document may be obtained from library sources, or by contacting the author of the report.

Christine Janda and Nancy Stricker are acknowledged for their research in updating and locating bibliographic information for this compilation. 



\section{VOLCANO HAZARDS PROGRAM BIBLIOGRAPHY}

-A-

Alaska Volcano Observatory, 1993 Mt. Spurr's 1992 eruptions: Eos, v. 74, p. 217-222.

Arattano, M., W.Z., and Pierson, T.C., 1993, Application of kinematic wave theory to a debris flow at Lower Rudd Canyon, Farmington, Utah, in Novosad, S. and Wagner, P., eds. Landslides: Proceedings of the Seventh International Conference and Field Workshop on Landslides in Czech and Slovak Republics, 28 August-15 September, 1993, Balkema, Rotterdam, p.123-130.

$-\mathbf{B}-$

Baker, V.R. and Costa, J.E., 1987, Flood Power: in Mayer, L. and Nash, D., eds., Catastrophic Flooding, 18th Annual Geomorphology Symposium, p. 1-21.

Blodgett, J.C., Peschel, K.R., and Thornton, J.L., 1988, A water-resources appraisal of the Mount Shasta area in northern California, 1985: U.S. Geological Survey Water-Resources Investigations Report 87-4239, 46 p.

Brugman, M.M., and Post, Austin, 1981, Effects of volcanism on the glaciers of Mount St. Helens: U.S. Geological Survey Circular 850-D, 11 p.

$-\mathrm{C}-$

Cameron, K.A., and Major, J.J., 1987, Reconnaissance investigation of sediment distribution, erosion, and transport in the upper Deschutes River, Deschutes County, Oregon, November 1986: U.S.Geological Survey Water-Resources Investigation Report 87-4114, p. 24.

Cameron, K.A., and Major, J.J., 1987, Geomorphic and hydrologic adjustments to dam closure and the effect on brown trout spawning habitat, upper Deschutes River, Oregon: [abs.] Northwest Scientific Association Annual Meeting, March 1987, Tacoma, Wash., no. 93.

Cameron, K.A., and Pringle, P.T., 1987, A detailed chronology of the most recent eruption period at Mount Hood, Oregon: Geological Society of America Bulletin, v. 99, p. 845-851.

Childers, D., and Carpenter, P.J., 1985, A warning system for hazards resulting from breaches from lake blockage, Mount St. Helens, Washington: in International Symposium on Erosion, Debris Flows, and Disaster Prevention, September 3-5, 1985, Tsukuba, Japan, p. 493-498.

Childers, D., Hammond, S.E., and Johnson, W.P., 1987, Hydrologic data for computations of sediment discharges for the North Fork Toutle Rivers near Mount St. Helens, Washington, 1980-1984: U.S. Geological Survey Open-File Report 87-548, 117 p.

Childers, D. and Janda, R.J., 1987, Magnitude and trends of suspended-sediment yields in the Toutle River basin following the 1980 eruptions of Mount St. Helens, Washington [abs.]: in Proceedings International Union of Geodesy and Geophysics, XIX General Assembly, Vancouver, Canada, v. 3, p. 981 . 
Clark, P.U., and Walder, J.S., 1994, Subglacial drainage and deforming beds beneath the Laurentide, British and Scandinavian ice sheets: Geological Society of America Bulletin.

Collier, C.R., McGavock, E.H., and Meyer, William, 1980, Hydrologic surveillance and investigations in Mount St. Helens area by Water Resoures Division, U.S. Geological Survey, [abs.]: EOS, Transactions of the American Geophysical Union, v. 61, no. 46, p. 955.

Costa, J.E., 1986, A history of paleoflood hydrology in the United States, 1800-1970: EOS, v. 67, no. 17, p. 425, 428-430. (Reprinted in History of Hydrology, Landa, E.R., and Ince, S., eds.: History of Geophysics, American Geophysical Union, v. 3, p. 49-53.

- 1987, Flood hazards of moraine-dam failures, [abs.]: Geological Society of America Abstracts with Programs, v. 19, p. 628.

- 1987, Hydraulics and basin morphology of the largest flash-floods in the conterminous United States: Journal of Hydrology, v. 93, p. 313-338.

- 1987, A comparison of the largest rainfall-runoff floods in the United with those of the Peoples Republic of China and the World: Journal of Hydrology, v. 96, p. 101-115.

_ 1988, Paleoflood hydrology: Physics Today, v. 41, p. 540-541.

— 1988, Floods from dam failures: in Baker, V.R., Kochel, R.C., and Patton, P.C., eds.: Flood Geomorphology, New York, John Wiley \& Sons, Inc., p. 439-463.

Mediterranean countries, WARREDOC (Natural Research Council of Italy), Perugia, Italy, p. 3.

, 1988, Rheologic, geomorphic, and sedimentologic differentiation of water floods, hyperconcentrated flows, and debris flows: in Baker, V.R., Kochel, R.C., and Patton, P.C., eds.: Flood Geomorphology, New York, John Wiley \& Sons, p. 113-122.

1991, Review of the book, "Floods: hydrological, sedimentological, and geomorphological implications": Bevins, K. and Carling, P. A., eds., Sedimentology, v. 38, p. 180-181.

1991, Nature, dynamics, and mitigation of the Val Pola landslide, Valtellina, Italy, 1987-88: Zeitschrift fur Geomorphologie, v. 35, p. 15-38.

1992, Characteristics of a debris fan formed at the U.S. Geological Survey debris-flow flume, H. J., Andrew Experimental Forest, Blue River, Oregon: [abs.] EOS, Transactions of the American Geophysical Union, v. 73, no. 43, p. 227.

Costa, J.E., and Schuster, R.L., 1988, The formation and failure of natural dams: Geological Society of America Bulletin, v. 100, p. 1054-1068.

— 1991, Documented historical landslide dams from around the world: U.S. Geological Survey Open-File Report 91-239, 491 p. (computer disk).

Costa, J.E. and Sylvester, A.G., 1993, Geoscience publications in the 1990's: the Editors' view: Geological Society of America Abstracts with Programs, v. 25, no. 6, p. A-145.

Costa, J.E., and Wieczorek, G.F., eds., 1987, Debris flows/avalanches: Process, recognition, and mitigation: Reviews in Engineering Geology, v. VII, Geological Society of America, 248 p. 
Cummans, J., 1981, Mudflows resulting from the May 18, 1980, eruption of Mount St. Helens, Washington: U.S. Geological Survey Circular 850-B, 16 p.

, 1981, Chronology of mudflows in the South Fork and North Fork Toutle River following the May 18 eruption, in Lipman, P.W., and Mullineaux, D.R., eds., The 1980 Eruptions of Mount St. Helens, Washington: U.S. Geological Survey Professional Paper 1250, p. 479-486.

\section{-D-}

Danskin, W.R., Farrar, C.D., and Dreiss, S.J., 1991, Ground-water basins along the eastern Sierra Nevada: Tectonics, water, and politics, in Walawender, M.J., and Hanan, B.B., eds., Geological excursions in southern California and Mexico: Geological Society of America Annual Meeting, San Diego, California, 1991, Guidebook, p. 447-473.

Denlinger, R.P., and Iverson, R.M., 1990, Limiting equilibrium and liquefaction potential in infinite submarine slopes: Marine Geotechnology, v. 9, p. 299-312.

Denlinger, R.P., Scott, K.M., Pierson, T.C., 1984, Granular resorting and its effect on resistance to flow in grain-supported lahars, [abs.]: EOS, Transactions of the American Geophysical Union, v. 65, p. 1142 .

Dinehart, R. L., 1983, Patterns of sediment concentration in hyperconcentrated flows at Mount St. Helens [abs.]: EOS, v. 64, p. 707.

1986, Sediment: data for streams near Mount St. Helens, Volume 2, Water Years 1981-83: U.S. Geological Survey Open-File Report 85-632, 438 p.

1987, Vertical profiles of velocity and suspended sediment in streams near Mount St. Helens, Washington: U.S. Geological Survey Open-File Report 87-377, 140 p.

1989, Dune migration in a steep, coarse-bedded stream: Water Resources Research, v. 25, no. 5 , p. 911-923.

1990, Evolution of coarse-gravel bedforms-Field measurements at flood stage: [abs.]: EOS, Transactions of the American Geophysical Union, v. 71, no. 43, p. 1343.

1992, Sediment data for streams near Mount St. Helens, Washington, Volume 3, Water Years 1984-87: U.S. Geological Survey Open-File Report 91-219, 179 p.

1992, Gravel-bed deposition and erosion by bedform observed ultrasonically during storm flow, North Fork Toutle River, Washington: Journal of Hydrology, v. 136, p. 51-71.

1992, Evolution of coarse-gravel bedforms: Field measurements at flood stage: Water Resources Research, v. 28, n. 10, p. 2667-2689.

1992, Sonar monitoring of gravel-transport processes at a stream-gaging station in a disturbed watershed [abs.], in Proceedings 1992 International Association for Hydrological Sciences Meeting, Erosion and Sediment Transport Monitoring Programs in River Basins, Oslo, Norway, August 24-28, 1992, p. 71-76. 
1990: Data collection and analysis: U.S. Geological Survey Water-Supply Paper.

Dinehart, R.L., Culbertson, J.K., 1982, Sediment-discharge characteristics of the Toutle River following the Mount St. Helens eruption, [abs.]: in Proceedings from the Conference on Mount St. HelensEffects on water resources: State of Washington Water Research Center, p. 149.

Dinehart, R.L., Finneran, S.D., Hendrix, D.J., 1984, The sediment sample data system: High-tech mudslinging: WRD Bulletin, v. January-June 1984.

Dinehart, R.L., Ritter, J.R., Knott, J.M., 1981, Sediment data for streams near Mount St. Helens: Volume 1, Water Year 1980, U.S. Geological Survey Open-File Report 81-822, p. 82.

Dion, N.P., Embrey, S.S., 1981, Effects of Mount St. Helens eruption on selected lakes in Washington: U.S. Geological Survey Circular 850-G, 25 p.

Dorava, J. M., 1991, Flood magnitude estimates of the Drift River flow resulting from the 1989-90 Redoubt Volcano eruptions [abs.]: in American Water Resources Association, Alaska Chapter Proceedings of 1991 Annual Conference, April 8 \& 9, 1991.

, 1991, Generalized stream channel evolution resulting from the 1989-90 eruptions of Redoubt Volcano: Alaska [abs.]: EOS, Transactions of the American Geophysical Union, v. 71, p. 4.

— 1992 , Geomorphic response to the 1989-90 eruptions of Redoubt Volcano, Alaska [abs.]: in American Water Resources Association, Alaska Chapter Proceedings of 1992 Annual Conference, April $9 \& 10,1992, p$.

Dorava, J.M., May, B.A., Meyer, D.F., and Myers, L.V., 1993, Channel geometry data of streams in the lower Drift River basin affected by the 1989-90 eruptions of Redoubt Volcano, Alaska: in U.S. Geological Survey Open-File Report 93-94, 66 p.

Dorava, J.M., and May, B.A., 1993, Challenges in real-time data collection at active volcanoes in the Pacific Northwest, the Philippines, and Alaska [abs.]: in American Water Resources Association, Alaska Chapter Proceedings of 1993 Annual Conference, April 8 \& 9, 1993, p. 1.

Dorava, J.M., and Meyer, D.F., Hydrologic hazards in the lower Drift River basin associated with the 1989-90 eruptions of Redoubt Volcano, Alaska: Journal of Volcanology and Geothermal Research, v. 62 , no. $1-4$, p. $387-407$.

Driedger, C.L., 1980, The effects of ash thickness on snow and firn ablation [abs.]: EOS, Transactions of the American Geophysical Union, v. 61, no. 46, p. 1150.

- 1981, Effects of ash thickness on snow ablation, in Lipman, P. W., and Mullineaux, D. R., eds., The 1980 eruptions of Mount St. Helens, Washington: U.S. Geological Survey Professional Paper 1250, p. 757-760

- 1986, A visitors guide to Mount Rainier glaciers: Seattle, Pacific Northwest National Parks and Forests Association, $80 \mathrm{p}$.

, 1988, Geology in action-jokulhlaups on Mount Rainier: U.S. Geological Survey Water Fact Sheet, Open-File Report 88-459, 2 p. 
1993, Glaciers on Mount Rainier: U.S. Geological Survey Water Fact Sheet, Open-File Report 92-474, 2 p.

Driedger, C.L., and Fountain, A.G., 1989, Analysis of recent glacial outburst floods on Mount Rainier: Annals of Glaciology, 1988, p. 51-59.

Driedger, C.L., and Kennard, P.M., 1986, Ice volumes on the Cascade Volcanoes: Mount Rainier, Mount Hood, Three Sisters, and Mount Shasta: U.S. Geological Survey Professional Paper $1365,28 \mathrm{p}$.

1986, Glacier volume estimation on Cascade volcanoes-An analysis and comparison with other methods: Annals of Glaciology, p. 59-64.

Driedger, C.L., and Walder, J.S., 1991, Recent debris flows at Mount Rainier: U.S. Geological Survey Water Fact Sheet, Open-File Report 91-242, 2 p.

\section{$-\mathbf{E}-$}

Ellen, S.D., Iverson, R.M., and Pierson, T.C., 1991, Map showing the distribution of debris flows during the New Year's Eve storm of 1987-1988 in southeastern Oahu, Hawaii: U.S. Geological Survey Open-File Report 91-129, 1 sheet.

Embrey, S.S., and Dion, N.P., 1988, Effects of the 1980 eruption of Mount St. Helens on the limnological characteristics of selected lakes in western Washington: U.S. Geological Survey Water-Resources Investigations Report 87-4263, 60 p.

- F-

Farrar, C.D., 1985, Electronic instrumentation for monitoring the hydrologic system of Long Valley: California [abs.]: EOS, Transactions of the American Geophysical Union, v. 66, no. 46, p. 911.

1991, Hydrogeology of the interstratified volcanic rocks and glacial deposits in Mammoth basin, Mono County, California [abs.]: Geological Society of America, Abstracts with programs, v. 23 , no. 5 , p. 215.

Farrar, C. D., and Lyster, D. L., 1990, Monitoring the hydrologic system for potential effects of geothermal and ground-water development in the Long Valley caldera, Mono County, California, U.S.A.: in 1990 International Symposium on Geothermal Energy, Kailua-Kona, Hawaii, August 20-24, Transactions: Davis, California, Geothermal Resources Council, v. 14, Part 1, p. 669-674.

_ 1991, Hydrologic monitoring for effects of geothermal and ground-water development, Long Valley caldera, California, in Symposium on Subsurface Injection of Geothermal Fluids, Santa Rosa, California, October 29-30, 1990, Proceedings: Oklahoma City, Oklahoma, Underground Injection Practices Council, p. 157-171.

Farrar, C.D., and Sorey, M.L., 1985, Monitoring the hydrothermal system in Long Valley caldera, California: Geothermal Resources Council Transactions, v. 9, Part 1, p. 423-428. 
Farrar, C.D., Sorey, M.L., Rojstaczer, S.A., Janik, C.J., Mariner, R.H., Winnett, T.L., and Clark, M.D., 1985, Hydrologic and geochemical monitoring in Long Valley caldera, Mono County, California, 1982-1984: U.S. Geological Survey Water-Resources investigations Report, 85-4183, 137 p.

Farrar, C.D., Sorey, M.L., Rojstaczer, S.A., Janik, C.J., Winnett, T.L., and Clark, M.D., 1987, Hydrologic and geochemical monitoring in Long Valley caldera, Mono County, California, 1985: U.S. Geological Survey Water-Resources Investigations Report 87-4090, 71 p.

Farrar, C. D., Sorey, M. L., and Rojstaczer, S. A., 1987, Hydrologic and geochemical monitoring in Long Valley caldera, California, in Goldstein, N. E., eds., Symposium on the Long Valley caldera: A pre-drilling data review, March 17-18, Proceedings: Berkeley, California, Lawrence Berkeley Laboratory, p. 12-15.

Farrar, C. D., Sorey, M. L., Rojstaczer, S. A., Steinemann, A. C., and Clark, M. D., 1989, Hydrologic and geochemical monitoring in Long Valley caldera, Mono County, California, 1986: U.S. Geological Survey Water-Resources Investigations Report 89-4033, 69 p.

Farrar, C.D., Sorey, M.L., Marshall, G.A., Howle, J.F., and Ikehara, M.E., Deformation in the Casa Diablo geothermal well field, Long Valley caldera, eastern California, in Prince Keith, Galloway and Stan Leake, eds., Proceedings of the U.S. Geological Survey Subsidence Interest Group Meeting, Edwards Air Force Base, California, November 17-19, 1992.

Fowler, A., and Walder, J., 1993, Creep closure of channels in deforming subglacial till: Proceedings of the Royal Society of London, Series A, v. 441, p. 17-31.

Foxworthy, B.L., and Hill, Mary, 1982, Volcanic eruptions of 1980 at Mount St. Helens, the first 100 days: U.S. Geological Survey Professional Paper 1249, $125 \mathrm{p}$.

Fust , L.A., 1981, Effects of the Mount St. Helens eruption on the benthic fauna of the Toutle River, Muddy River, and Pine Creek drainage basins, Washington: U.S. Geological Survey Circular $850-\mathrm{H}, 13 \mathrm{p}$.

\section{$-\mathbf{G}-$}

Gallino, G.L., Pierson, T.C., 1984, Polallie Creek debris flow and subsequent dam-break flood of 1980, East Fork Hood River basin, Oregon: U.S. Geological Survey Water-Supply Paper 2273, $22 \mathrm{p}$.

Glicken, Harry, 1986, Rockslide-debris avalanche of May 18, 1980, Mount St. Helens Volcano: Santa Barbara, Calif., University of California, Ph.D. thesis, 303 p.

Glicken, Harry, Janda, R.J., Voight, Barry, 1980, Catastrophic landslide/debris avalanche of May 18, 1980, Mount St. Helens Volcano, [abs.]: EOS, Transactions of the American Geophysical Union, v. 61 , no. 46 , p. 1135 .

Glicken, Harry, Meyer, William, Carpenter, P.J., Sabol, M.A., Swift, C.H., and Kresch, D.L., 1983, Actual and potential volcanic lake breakouts at Mount St. Helens, Washington [abs.]: EOS, Transactions of the American Geophysical Union, v. 64, no. 45, p. 894.

Glicken, Harry, Meyer, William, and Sabol, M. A., 1989, Geology and ground water hydrology of Spirit Lake blockage, with implications for lake retention: U.S. Geological Survey Bulletin 1789, 33 p., 3 plates. 
Glicken, Harry, Voight, Barry, Janda, R.J., Rockslide-debris avalanche of May 18, 1980, Mount St. Helens Volcano, [abs.] 1981, IVACEI Symposium on ARC Volcanism, Aug. 28-Sept. 9, 1981, Japan, p. 109-110.

Glicken, Harry, Voight, Barry, in press, Geology of the North Fork Toutle River blockages, in Schuster, R.L., and Meyer, W., eds., Major lakes impounded by the May 18, 1980, eruption of Mount St. Helens, and stability of their blockages: U.S. Geological Survey Professional Paper.

H.

Haeni, F.P., 1983, Sediment deposition in the Columbia and lower Cowlitz Rivers, Washington-Oregon, caused by the May 18, 1980, eruption of Mount St. Helens: U.S. Geological Survey Circular $850-K, 21$ p.

Hammond, S.E., 1987, Comparison of sediment-transport formulas and computations of sediment discharges for the North Fork Toutle and Toutle Rivers near Mount St. Helens, Washington-A preliminary report: U.S. Geological Survey Administrative Report, $18 \mathrm{p}$.

Herkelrath, W.N., Hubbell, D.W., Laenen, J.M., and McKenzie, S.W., 1983, Characteristics of Columbia River sediment following the eruption of Mount St. Helens on May 18, 1980: U.S. Geological Survey Circular 850-J, 21 p.

Hromadka, T.V., II, Berenbrock, C.E., Freckleton, J.R., and Guymon, G.L., 1985, A two-dimensional dam-break flood plain model: Advances in Water Resources, v. 8, p. 7-14.

Hubbell, D.W., Laenen, J.M., and McKenzie, S.W., 1983, Characteristics of Columbia River sediment following the eruption of Mount St. Helens on May 18, 1980: U.S. Geological Survey Circular 850-J.

\section{-I-}

Iverson, R.M., 1985, Minor Creek landslide, in Redwood Country: in M.E. Savina, ed., American Geomorphological Field Group Field Trip Guidebook, p. 40-50.

- 1986, Book review of "Slope Instability," Brunsden, D. and Prior, D.B., eds., Journal of Geology, v. 94, no. 3, p. 446-447.

__- 1986, Dynamics of slow landslides: A theory for time-dependent behavior, in Abrahams, A.D., ed., Hillslope Processes: Boston, Allen and Unwin, p. 297-317.

- 1986, Groundwater flow and mass-movement dynamics, [abs.]: EOS, Transactions of the American Geophysical Union, v. 67, no. 16, p. 242.

- 1989, Pore-water effects in mass-movement mechanics: Abstracts, 28th International Geological Congress, v. 2, p.104-105.

, 1990, Lava domes modeled as brittle shells that enclose pressurized magma, with application to Mount St. Helens: in Fink, J., ed., Lava flows and domes: Proceedings in Volcanology, Volume 2: Berlin, Springer-Verlag, p. 47-69. 
-1 , 1990, Groundwater flow-field in infinite slopes: Geotechnique, v. 40, no. 1, p. 139-143.

, 1990, Pore-pressure effects in giant landslides on oceanic volcanoes [abs.]: EOS, Transactions of the American Geophysical Union, v. 71, no. 43, p. 1578.

1991, Failure and runout of giant landslides on Hawaiian volcanoes: Cases of enigmatic mechanics? [abs.]: Geological Society of America Abstracts with Programs, v. 23, no. 5, p. A-125.

, 1992, Sensitivity of stability analyses to groundwater data: in Bell, D.H., ed., Landslides (Proceedings of the Sixth International Symposium on Landslides, Volume 1): Balkema, Rotterdam, p. 451-457.

, 1992, Rigid-wedge models for metastable flanks of Hawaiian volcanoes: [abs.], EOS, Transactions of the American Geophysical Union, v. 73, no. 43, p. 505.

- 1993, Differential equations governing slip-induced pore-pressure fluctuations in a watersaturated granular medium: Mathematical Geology, v. 25, no. 8, p. 1073-1094. ofty

_- in press, Can magma-injection and groundwater forces cause massive landslides on Hawaiian volcanoes?: Journal of Volcanology and Geothermal Research.

Iverson, R.M., Costa, J.E., and LaHusen, R.G., 1992, Debris-flow flume at H. J., Andrew Experimental Forest, Oregon: U.S. Geological Survey Water Fact Sheet, Open-File Report 92-483, 2 p. (Reprinted in Landslide News, 1993, no. 7, p. 29-31.

Iverson, R.M., and Denlinger, R.P., 1989, A mechanical model for lava domes that includes a mechanism for eruptive growth: Continental Magmatism: Abstracts, International Association of Volcanology and Chemistry of the Earth's Interior, General Assembly, p. 141.

Iverson, R.M., and Driedger, C.L., 1993, Hydrology and motion of Minor Creek landslide: Long-term response to deluge and drought [abs.]: EOS, Transactions of the American Geophysical Union, v. 74 , no. 43, p. 300 .

Iverson, R.M., and LaHusen, R.G., 1988, High-frequency pore-pressure fluctuations in rapidly shearing Coulomb materials-experimental evidence and mechanical implications: [abs.], EOS, Transactions of the American Geophysical Union, v. 69, no. 16, p. 484.

- 1988 , Dynamic pore-pressure fluctuations in rapidly shearing granular materials: theory: [abs.], EOS, Transactions of the American Geophysical Union, v. 69, no. 44, p. 1195.

,1989, Dynamic pore-pressure fluctuations in rapidly shearing granular materials: Science, v. 246 , no. 4931 , p. $796-799.1$

, 1991, Debris-flow experiments with a large-scale hillside flume [abs.]: EOS, Transactions of the American Geophysical Union, v. 72, no. 44, p. 228.

- 1993, Friction in debris flows: Inferences from large-scale flume experiments: in Hydraulic Engineering ' 93 (Proceedings of the 1993 Conference of the Hydraulics Division of the American Society of Civil Engineers), v. 2, p. 1604-1609.

, 1993, Pore-pressure dynamics in debris-flow experiments [abs.]: EOS, Transactions of the American Geophysical Union, v. 74, no. 43, p. 310. 
Iverson, R.M., LaHusen, R.G., Harrison, E.A., and Davis, C.J., 1989, Dynamic pore-pressure fluctuations in rapidly shearing granular media: Geophysical Grain Flows, Proceedings of a Research Seminar at Scripps Institution of Oceanography, sponsored by the National Science Foundation and Office of Naval Research, p. 28.

Iverson, R. M., Major, J. J., 1985, Subsurface hydrology of a persistently active landslide: Implications for slope movement, [abs.]: EOS, Transactions of the American Geophysical Union, v. 66, no. 46, p. 898 .

- 1985, Darcian seepage, Coulomb failure and liquefaction in soil-mantled slopes, [abs.]: EOS, Transactions of the American Geophysical Union, v. 66, no. 46, p. 898.

- 1986, Groundwater seepage vectors and the potential for hillslope failure and debris-flow mobilization: Water Resources Research: v. 22, p. 1543-1548.

- 1987, Rainfall, groundwater flow, and seasonal movement at Minor Creek landslide, Northwestern California-Physical interpretation of empirical relations: Geological Society of America Bulletin, v. 99, p. 579-594.

Iverson, R. M., and Reid, M. E., 1992, Gravity driven groundwater flow and slope failure potential: 1. Elastic effective-stress model: Water Resources Research, v. 28, no. 3, p. 925-938.

\section{$-\mathrm{J}-$}

Janda, R. J., 1981, Hydrologic phenomena associated with explosive Cascades volcanism, [abs.]: EOS, Transcations of the American Geophysical Union, v. 62, no. 45, NRC-sponsored Symposium on Explosive Volcanism.

, 1985, Sediment storage and discharge in steep unstable terrain, [abs]: in Glysson, G.D. ed., Proceedings of the Advanced Seminar on Sedimentation, August 15-19, 1983, Denver, Colorado: U.S. Geological Survey Open-File Report 85-98, p. 61-62.

1987, Erosion in Pacific Rim steeplands following explosive volcanism [abs.]: In Proceedings International Union of Geodesy and Geophysics, XIX General Assembly, Vancouver, Canada, v. 3 ,

Janda, R.J., Banks, N.G., Pierson, T.C., Calvache, M.L., Thouret, J.C., 1986, Interaction between ice and pyroclastic sediments erupted during the 13 November eruption of Nevado del Ruiz, Colombia, [abs.]: EOS, Transactions of the American Geophysical Union, v. 67, no. 16, p. 406.

Janda, R.J., Major, J.J., Pierson, T.C., Waitt, R.B. Jr., and Miller, T.P., 1990, Downstream changes in 1989-90 debris flows and floods from glacier-clad Redoubt Volcano, Alaska: [abs.] EOS, Transactions of the American Geophysical Union, v. 71, no. 43, p. 1706.

Janda, R.J., Major, J.J., Scott, K.M., Besana, G., Daligdid, J.A., and Daag, A.S., 1991, Lahars accompanying the mid-June 1991 eruptions of Mount Pinatubo, Tarlac and Pampanga Provinces, The Philippines: [abs.] EOS, Transactions of the American Geophysical Union, v. 72, n. 44, p. 62. 
Janda, R.J., Meyer, D.F., Childers, D., 1984, Sedimentation and geomorphic changes during and following the 1980-1983 eruptions of Mount St. Helens, Washington (in two parts): Shin-Sabo Japan, v. 37, n. 2, p. 10-21, and v. 37, n. 3, p. 5-19.

Janda, R.J., Meyer, D.F., 1985, Channel morphology changes caused by debris flow, hyperconcentrated streamflow, and sediment-laden streamflow, Toutle River, Mount St. Helens, Washington: in Proceedings of the International Workshop on Flow at Hyperconcentrations of Sediment, Sept. 10-14, 1985, Beijing, China, p. III-17 to III-29.

, 1985, Fluvial sedimentation following Quaternary eruptions of Mount St. Helens, Washington, [abs.]: Abstracts with Program, Geological Society of America, Annual Meeting, 1985, Orlando, Florida, p. 618.

1986, Sediment concentration and channel morphology: in Proceedings of the Fourth Federal Interagency Sedimentation Conference, March 24-27, 1986, Las Vegas, Nevada, p. 3-83 to 3-92.

Janda, R.J., Nolan, K.M., Glicken, H., Abbott, L.S., Voight, B., 1980, Processes responsible for massive river sedimentation following the May 18, 1980 eruption of Mount St. Helens, [abs.]: EOS, Transactions of the American Geophysical Union, v. 61, no. 46, p. 955-956.

Janda, R.J., Scott, K.M., Nolan, K.M., Martinson, H.A., 1981, Lahar movement, effects, and deposits: in Lipman, P.W., and Mullineaux, D.R., eds. The 1980 eruptions of Mount St. Helens, Washington: U.S. Geological Survey Professional Paper 1250, p. 461-478.

, 1981, Lahars associated with the 1980 eruption of Mount St. Helens, [abs.]: in Proceedings, conference on Mount St. Helens: Effects on water resources, Oct. 7-8, 1981, Jantzen Beach, Oregon: State of Washington Water Research Report 41, p. 163.

Jennings, M.E., Schneider, V.R., and Smith, P.E., 1981, Emergency assessment of Mount St. Helens post-eruption flood hazards, Toutle and Cowlitz Rivers, Washington: U.S. Geological Survey Circular 850-I, 17 p.

Jonientz-Trisler, C., Driedger, C.L., Qamar, A., 1989, Seismic signatures of debris flows on Mount Rainier, WA, [abs.]: EOS, Transactions of the American Geophysical Union, Proceedings of Pacific Northwest Regional Meeting., Seattle, Wash., September 1989.

Jonientz-Trisler, C., Driedger, C.L., 1990, Seismic evidence of historic debris flows and dry-season floods on Mount Rainier, Washington, 1961-1990, [abs.]: EOS, Transactions of the American Geophysical Union, v. 71 , no. 41 , p. 1145.

\section{$-\mathbf{K}-$}

Kennard, P.M., and Driedger, C.L., 1987, Estimated ice volumes on Cascade volcanoes: Mount Baker, Glacier Peak, and Mount Adams in Washington, and Mount Jefferson in Oregon [abs.]: EOS, Transactions of the American Geophysical Union, v. 68, no. 16, p. 308.

Klein, J.M., 1984, Some chemical effects of the Mount St. Helens eruption on selected streams in the State of Washington: U.S. Geological Survey Circular 850-E, 26 p.

Kresch, D.L., 1985, Spirit Lake dam-failure flood routing assessment: U.S. Geological Survey OpenFile Report 82-770, 8 p. 
1992, Development and routing of mudflow resulting from hypothetical failure of Spirit Lake debris dam, Washington: U.S. Geological Survey Water-Resources Investigations Report 91-4028.

Kresch, D.L., and Laenen, A., 1983, Preliminary assessment of possible flood elevations in the Columbia River at Trojan Nuclear Power Plant due to failure of the debris dam blocking Spirit Lake, Washington: U.S. Geological Survey Water-Resources Investigation 83-4197.

\section{$-\mathbf{L}-$}

Laenen, A., and Hansen, R.P., 1988, Simulation of three lahars in the Mount St. Helens area, Washington, using a one-dimensional, unsteady-state streamflow model: U.S. Geological Survey Water-Resources Investigations Report 88-4004,

Laenen, A., and Orzol, L.L., 1987, Flood hazards along the Toutle and Cowlitz Rivers, Washington, from a hypothetical failure of Castle Lake blockage: U.S. Geological Survey Water-Resources Investigations Report 87-4005.

Laenen, A., Scott, K.M., Costa, J.E., and Orzol, L.L., 1987, Hydrological hazards along Squaw Creek from a hypothetical failure of the glacial moraine impounding Carver Lake near Sisters, Oregon: U.S. Geological Survey Open-File Report 87-41, 48 p.

, 1992, Modeling flood flows from a hypothetical failure of the glacial moraine impounding Carver Lake near Sisters, Oregon; in Subitzky, S., ed., Selected Papers in the Hydrologic Sciences: U.S. Geological Survey Water-Supply Paper 2340, p. 151-164.

LaHusen, R.G., and Iverson, R.M., 1988, Dynamic pore-pressure fluctuations in rapidly sharing granular materials: field-scale experiments [abs.]: EOS, Transactions of the American Geophysical Union, v. 69 , no. 44 , p. 1195.

Leavesley, G.H., 1981, Physical properties of ash from Mount St. Helens-Relationship to rain infiltration experiments, [abs.]: Agronomy Abstracts, p. 141.

Lee, Douglas, B., in press, The effects of the eruption of Mount St. Helens on physical, chemical, and biological characteristics of surface water, ground water, and precipitation in the western United States: U.S. Geological Survey Water-Supply Paper.

Lisle, T.C., Lehre, A.K., Martinson, H.A., Meyer, D.F., Nolan, M.K., Smith, R.D., 1983, Stream channel adjustments after the 1980 Mount St. Helens eruptions: in Proceedings Symposium on Erosion Control in Volcanic Areas, Seattle and Vancouver, Washington, july 6-9, 1982, Technical Memorandum of Public Works Research Institute, Ministry of Construction, Government of Japan, p. 31-72.

Lockwood, J.P., Costa, J.E., and Tuttle, M.L., 1987, The potential for disastrous failure of a natural pyroclastic dam at Lake Nyos, Cameroon [abs.]: EOS, Transactions of the American Geophysical Union, v. 68, no. 16 , p. 1551.

Lockwood, J.P., Costa, J.E., Tuttle, M.L., Nni, J., and Tebor, S.G., 1988, The potential for catastrophic dam failure at Lake Nyos maar, Cameroon: Bulletin of Volcanology, v. 50, p. 340-349.

Lombard, R.E., 1986, Channel geometry, flood elevations, and flood maps, lower Toutle and Cowlitz Rivers, Washington, June 1980 to May 1981: U.S. Geological Survey Water-Resources Investigations Report 85-4080, 34 p. 
Lombard, R.E., Miles, M.B., Nelson, L.M., Kresch, D.L., and Carpenter, P.J., 1981, Channel conditions in the lower Toutle and Cowlitz Rivers resulting from the mudflows of May 18, 1980: U.S. Geological Survey Circular, 850-C, 16 p.

\section{$-\mathrm{M}$ -}

Major, J.J., 1984, Geologic and rheologic characteristics of the May 18, 1980, southwest flank lahars, Mount St. Helens, Washington: University Park, Penna., The Pennsylvania State University, M.S. thesis, 225 p.

, 1987, Mount St. Helens dome erodes through rockfalls, avalanches: The Oregonian Newspaper, Science insert, September 10, 1987, Portland, Oreg.

_ 1991, Destructive geomorphic processes on volcanoes [abs]: EOS, Transactions of the American Geophysical Union, v. 72, n. 44, p. 228.

, 1993, Rheometry of natural sediment slurries: in Hydraulic Engineering '93, Proceedings of 1993 ASCE (American Society of Chemical Engineers) National Conference on Hydraulic Engineering, July 25-30, 1993, San Francisco, Calif., p. 1415-1421.

Major, J.J., Burnett, A.W., 1984, Stratigraphy and potential hazards of lahars in the Hood River valley, Oregon, [abs.]: Oregon Academy of Sciences annual meeting, February 1984, Eugene, Oreg.

Major, J.J., and Iverson, R.M., 1985, Subsurface hydrology of a persistently active landslide: Implications for slope movement [abs.]: EOS, Transactions of the American Geophysical Union, v. 66, n. 46, p. 898 .

- 1988, Discussion of "Hydroseismicity - A hypothesis for the role of water in the generation of intraplate seismicity" by Costain, J.K., Bollinger, G.A., and Speer, J.A.,: Geology, v. 16, p. 562-563.

1993, Is the dynamic behavior of a debris flow recorded by its deposit? [abs.]: EOS, Transactions of the American Geophysical Union, v. 74, no. 43, p. 315.

Major, J.J., and Janda, R.J., 1990, Channel instability induced by debris flows and floods during the 1989-90 eruptions of Redoubt Volcano, Alaska [abs.]: EOS, Transactions of the American Geophysical Union, v. 71, no. 43, p. 1706.

Major, J. Janda, R., Pierson, T., Waitt, R., LaHusen, R., Scott, W. Trabant, D., Brabets, T., 1990, Debris flows and floods generated by eruption of Redoubt Volcano, Alaska: Consequences of interaction between snow and ice and volcanic debris [abs.]: Geological Society of America Abstracts with Programs, v. 22, p. A55.

Major, J.J., and Newhall, C.G., 1987, Effects of historic volcanic eruptions on snow and ice-A global review: [abs.] EOS, Transactions of the American Geophysical Union, v. 68, n. 16, p. 1550.

Major, J.J., and Newhall, C.G., 1989, Snow and ice perturbation during eruptions-Historical perspective on a significant volcanic-hydrologic hazard [abs.]: New Mexico Bureau of Mines and Mineral Resources Bulletin 131, Proceedings of IAVCEI General Assembly, Santa Fe, New Mexico, June 25-July 1, 1989, p. 174. 
- 1989, Snow and ice perturbation during historical volcanic eruptions and the formation of lahars and floods-A global review: Bulletin of Volcanology, v. 52, p. 1-27.

Major, J.J., and Pierson, T.C., 1990, Rheological analysis of fine-grained natural debris-flow material, in French, R.H., ed., Hydraulics/Hydrology of Arid Lands: Proceedings of ASCE (American Society of Chemical Engineers) International Symposium on Hydraulics/Hydrology of Arid Lands, San Diego, Calif., July 30-August 2, 1990, p. 225-231.

Major, J.J., and Pierson, T.C., 1992, Debris flow rheology: Experimental analysis of fine-grained slurries: Water-Resources Research, v. 28, p. $841-857$.

Major, J., Pringle, P., 1986, Rockfall-avalanches from the Mount St. Helens dome, March 1984, [abs.]: Northwest Scientific Association Annual Meeting, March 1986, Cheney, Washington, p. 169.

Major, J.J., and Scott, K.M., 1986, Downstream lahar deposits in the Lewis River system, Mount St. Helens, Washington [abs.]: in Guidebook to 1986 American Geomorphological Field Group Conference-Mount St. Helens, September 3-7, Cispus Center, Randle, Washington, p. 169.

, 1988, Volcaniclastic sedimentation in the Lewis River valley, Mount St. Helens, WashingtonProcesses, extent, and hazards: U.S. Geological Survey Bulletin 1383-D, 38 p.

Major, J.J., Voight, B., 1984, The Mount St. Helens southwest flank lahars of May 18, 1980: Flow dynamics, sedimentology, clast fabric, [abs.]: Geological Society of America Annual Meeting, v. 16,6, p. 583 .

- 1986, Sedimentology and clast orientations of the May 18, 1980, southwest flank lahars, Mount St. Helens, Washington: Journal of Sedimentary Petrology, v. 56, p. 691-705.

March, R.S., Mayo, L.R., and Trabant, D.C., 1986, Geodetic survey stations near Mount Spurr Volcano, Alaska: U.S. Geological Survey Open-File Report 86-137, 14 p.

Martinson, H.A., Finneran, S.D., Topinka, L.J., 1984, Changes in channel geomorphology of six eruption-affected tributaries of the Lewis River, 1980-82, Mount St. Helens, Washington: U.S. Geological Survey Open-File Report 84-614, 113 p.

Martinson, H.A., Hammond, H.E., Mast, W.W., Mango, P.D., 1985, Channel geometry and hydrologic data for six eruption-affected tributaries of the Lewis River, Mount St. Helens, Washington: U.S. Geological Survey Open-File Report 85-631, 161 p.

Martinson, H.A., Meyer, D.F., Janda, R.J., 1981, Storm-induced changes in channel morphology of mudflow-impacted streams, [abs]: in Proceedings Conference on Mount St. Helens: Effects on Water Resources, Oct. 7-8, 1981, Jantzen Beach, Oreg., Report 41, p. 253.

Martinson, H.A., Meyer, D.F., 1985, Stream channel adjustments to 1980 lahars and subsequent storm flow, Mount St. Helens, [abs.]: in Glysson, G.D., ed., U.S. Geological Survey Open-File Report 85-98, Proceedings of the Advanced Seminar on Sedimentation, Aug. 15-19, 1983, Denver, Colorado, p. 31-33.

Mastin, L.G., 1991, The roles of magma and groundwater in the phreatic eruptions of the Inyo Craters, Long Valley caldera, California: Bulletin of Volcanology, v. 53, p. 579-596. 
_ 1992, The dynamics of low-energy gas eruptions-An experimental approach [abs.]: EOS American Geophysical Union, v. 73, no. 43, p. 628.

1992, Correlation between atmospheric precipitation and recent explosions at Mount St. Helens, Washington: Earthquakes and Volcanoes, v. 23, p. 74-76.

, 1993, Can rain cause volcanic eruptions?: U.S. Geological Survey Water Fact Sheet, OpenFile Report 93-445, 2 p.

, 1994, Shallow explosion-like seismicity and gas-and-tephra emissions at Mount St. Helens, August 1989-June 1991: The violent escape of magmatic gas following storms: Geological Society of America Bulletin, v. 106, no. 2, p. 175-185.

Mastin, L., Heinemann, B.B., Krammer, A., Fuch, K., and Zoback, M.D., 1991, Stress orientation in the KTB pilot hole determined from stress-induced well bore breakout: Scientific Drilling, v. 2, p. 1-12.

Mastin, L.G., and Myers, Bobbie, 1991, Rainfall, steam eruptions, and surface changes on the lava dome at Mount St. Helens [abs.]: EOS, Transaction of the American Geophysical Union, v. 72, no. 44 , p. 227.

1992, Shallow explosion-like seismicity and stream-and-ash eruptions at Mount St. Helens, August 1989-June 1991: Washington Geology, v. 20, no. 2, p. 12-18.

McGimsey, R.G., and Dorava, J.M., 1992, Eruption of Mount Spurr Volcano, Alaska, August 18, 1992 - Video footage [abs.]: EOS, Transactions of the American Geophysical Union, v. 73, no. 43, p. 345-346.

McGimsey, R.G., Waythomas, C.F., and Neal, C.A., in press, High stand and catastrophic draining of intracaldera Surprise Lake, Aniakchak volcano, Alaska: U.S. Geological Survey Bulletin.

McKnight, D.M., Feder, Gerald L., and Stiles, Eric A., 1980. Effects on blue-green alga of leachates of ash from the May 18 eruption, in Lipman, P.W., and Mullineaux, D.L., eds. The 1980 eruptions of Mount St. Helens, Washington: U.S. Geological Survey Professional Paper 1250, p. 733-741.

_- 1981, Toxicity of Mount St. Helens ash leachate to a blue-green alga: U. S. Geological Survey Circular 850-F, $14 \mathrm{p}$.

McKnight, D.M., Klein, J.M., and Wissmar, R.C., 1984, Changes in the organic material in lakes in the blast zone of Mount St. Helens, Washington: U.S. Geological Survey Circular 850-L, 26 p.

McKnight, D.M., Periera, W.E., and Ceazan, M.L., 1982, Characterization of dissolved organic materials in surface waters within the blast zone of Mount St. Helens, Washington: Organic Geochemistry, v. 4 , p. $85-92$.

McKnight, D.M., Thorn, Kevin and Wershaw, Robert, 1987, Changes in dissolved organic material in Spirit Lake, Washington, USA: The Science of the Total Environment, v. 62, p. 189-192.

McKnight, D.M., Thorn, Kevin A., Wershaw, Robert L., Bracewell, J. Michael, and Robertson, Graeme, 1988, Rapid changes in dissolved humic substances in Spirit Lake and South Fork Castle Lake, Washington: Limnology and Oceanography, v. 33, no. 6, p. 1527-1541. 
Meier, M.F., Post, Austin, Krimmel, R.M., and Driedger, C.L., 1984, 1983 recession of Columbia Glacier, Alaska: U.S. Geological Survey Open-File Report 84-059, 10 p.

Meyer, D.F., 1989, The significance of sediment transport in arroyo development: U.S. Geological Survey Water-Supply Paper 2349, 61 p.

Meyer, D.F., Carpenter, P.J., Janda, R.J., 1981, Hydrologic effects of Mount St. Helens' 1980 eruptions: EOS, Transactions of the American Geophysical Union, v. 62, no. 33, p. 625-627.

Meyer, D.F., and Dodge, J.E., 1987, Post-eruption changes in channel geometry of streams in the Toutle River drainage basin, 1983-85, Mount St. Helens, Washington: U.S. Geological Survey Open-File Report 87-549, 226 p.

Meyer, D.F., Janda, R.J., Martinson, H.A., 1981, Initial and subsequent stream responses to the 1980 eruption of Mount St. Helens, [abs.]: American Geophysical Union, Pacific Northwest Section 1981 Meeting, Sept. 17-18, Ellensburg, Washington,

Meyer, D. F., Janda, R. J., 1985, Erosional development of the North Fork Toutle debris avalanche deposit, [abs.]: in Glysson, G.D., ed, U.S. Geological Survey Open-File Report 85-98, Proceedings of the Advanced Seminar on Sedimentation, Aug. 15-19, 1983, Denver, Colorado, p. 34-36.

1986, Sedimentation downstream from the 18 May 1980 North Fork Toutle River debris avalanche deposit, Mount St. Helens, Washington, in Keller, S.A.C., Proceedings of the Symposium Mount St. Helens: Five Years Later: Cheney, Washington, p. 68-86.

Meyer, D.F, and Martinson, H.A., 1987, Rates and processes of channel development and recovery following the 1980 eruption of Mount St. Helens, Washington [abs.]: Proceedings International Union of Geodesy and Geophysics, XIX General Assembly, Vancouver, Canada, v. 3, p. 980.

- 1989, Rates and processes of channel development and recovery following the 1980 eruption of Mount St. Helens, Washington: Hydrological Sciences Journal, v. 34, p. 115-127.

Meyer, D.F., Nolan, K.M., Dodge, J.E., 1985, Post-eruptive changes in channel geometry of streams in the Toutle River drainage basin, 1980-82, Mount St. Helens, Washington: U.S. Geological Survey Open-File Report 85-412, 128 p.

Meyer, D.F., and Trabant, D.C., 1992, Lahar-producing events and non-lahar producing events at glacier-clad Cook Inlet Volcanoes, Alaska: [abs.], EOS, Transactions of the American Geophysical Union, v. 73 , no. 43 , p. 346.

- in press, Lahars from the 1992 eruptions of Crater Peak, Mount Spurr Volcano, Alaska: U.S. Geological Survey Bulletin.

Meyer, W., Carpenter, P.J., 1982, Filling of Spirit Lake, Washington, May 18, 1980 to July 31, 1982: U.S. Geological Survey Open-File Report 82-771, 19 p.

Meyer, W., Sabol, M.A., Glicken, Harry, Voight, Barry, 1984, The effects of ground water, slope stability, and seismic hazard on the stability of the South Fork Castle Creek blockage in the Mount St. Helens area, Washington: U.S. Geological Survey Professional Paper 1345, 72 p. 
Meyer, William, Sabol, M. A., Glicken, Harry, and Voight, Barry, 1985, The effects of ground water, slope stability, and seismic hazard on the stability of the South Fork Castle Creek blockage in the Mount St. Helens area, Washington: U.S. Geological Survey Professional Paper 1345, 42 p.

Meyer, William, Sabol, M.A., Schuster, R.L., 1986, Landslide-dammed lakes at Mount St. Helens, Washington, in Proceedings of symposium on landslide dams: Processes, risk, and mitigation, Geotechnical Special Publication no. 3, American Society of Civil Engineers, p. 21-41.

1989, Landslide dammed lakes at Mount St. Helens, Washington [abs.], in Hodges, C.A., ed., Geohazards '88 symposium: U.S. Geological Survey Circular 1038, p. 18.

Meyer, William, and Sabol, M.A., 1989, Hydrology of the Castle Lake blockage, Mount St. Helens, Washington: U.S. Geological Survey Water-Resources Investigations Report 87-4272, 25 p.

$-\mathrm{N}-$

Nolan, K.M., Janda, R.J., Galton, J.H., 1986, Sediment sources and sediment transport curves, in Proceedings of the Fourth Federal Interagency Sedimentation Conference, March 27-27, 1986, Las Vegas, Nevada, p. 4-70 to 4-79.

-O-

O'Connor, J.E. and Costa, J.E., 1992, Geologic hazards in glacial basins accompanying 19th and 20th century global warming [abs.]: The World at Risk: Natural Hazards and Climate Change, Massachusetts Institute of Technology, Cambridge, Mass., p. 5.

- 1994, Geologic and hydrologic hazards in glacierized basins resulting from 19th and 20th century global warming: Natural Hazards, v. 8, no. 2, $20 \mathrm{p}$.

O'Connor, J.E., Costa, J.E., Clague, J.J., and Evans, S.G., 1993, Geomorphic consequences of 19th and 20th century glacier retreat in alpine basins of western North America [abs.]: Programme with Abstracts, Third International Geomorphology Conferences, Hamilton, Ontario, Canada, p. 208.

O'Connor, J.E., Hardison, J.H., and Costa, J.E., 1993, Debris flows from recently deglaciated areas on central Oregon Cascade Range volcanoes [abs.]: EOS, Transactions of the American Geophysical Union, v. 74 , no. 43, p. 314 .

Osterkamp, W.R., and Costa, J.E., 1986, Denudation rates in selected debris-flow basins: in Proceedings of the Fourth Federal Interagency Sedimentation Conference, v. 1, p. 4-91 to 4-99.

Osterkamp, W. R., and Costa, J. E., 1987, Changes accompanying an extraordinary flood on a sandbed stream: in Mayer, L. and Nash, D., eds., Catastrophic Flooding, 18th Annual Geomorphology Symposium, p. 201-224.

Osterkamp, W.R., Hupp, C.R., and Blodgett, J.C., 1986, Magitude and frequency of debris flows, and areas of hazard on Mount Shasta, northern California: U.S. Geological Survey Professional Paper 1396-C, $21 \mathrm{p}$. 
Packard, F.A., Meyer, William, Willaims, J.R., and Bender, Scott, in press, Possible causes and effects of a rise in ground-water levels in the lower Cowlitz River valley, Washington, since the 1980 Mount St. Helens eruption: U.S. Geological Survey Water-Resources Investigations Report 92-4158.

Paine, A.D., 1984, Canyon and terrace formation near Mount St. Helens, Washington: Fort Collins, Colorado, Colorado State University, M.S. thesis, 157 p.

Paine, A.D.M., Meyer, D.F., and Schumm, S.A., 1987, Incised channel and terrace formation near Mount St. Helens, Washington, in Erosion and Sedimentation in the Pacific Rim: International Association Hydrological Science Publication, no. 165, p. 389-390.

Pierson, T.C., 1981, Dominant particle support mechanisms in debris flows at Mount Thomas, New Zealand, and implications for flow mobility: Sedimentology, v. 28, p. 49-60.

1983, Soil pipes and slope stability: Quarterly Journal of Engineering Geology, London, v. 16, p. 1-11.

1983, Flow behavior of two major lahars triggered by the May 18, 1980, eruption of Mount St. Helens, Washington, in Proceedings of Symposium on Erosion Control in Volcanic Areas: Public Works Research Institute (Japan), Technical Memorandum No. 1908, p. 99-129.

1984, Why debris flows stop, [abs.]: Geological Society of America, Abstracts with Programs, v. 16 , no. 6, p. 623 .

, 1985, Effects of slurry composition on debris-flow dynamics, Rudd Canyon, Utah, in Bowles, D.S., ed., Delineation of landslide, flash flood, and debris-flow hazards in Utah: Utah Water Research Laboratory, General Series UWRL/G-85/03, Logan, Utah, p. 132-152.

1985, Field techniques for measuring debris-flow dynamics: in Proceedings of International Symposium on Erosion, Debris Flow, and Disaster Prevention: Tsukuba, Japan, Erosion-Control Engineering Society, p. 203-207.

- 1985, Initiation and flow behavior of the 1980 Pine Creek and Muddy River lahars, Mount St. Helens, Washington: Geological Society of America Bulletin, v. 96, p. 1056-1069.

, 1986, Flow behavior of channelized debris flows, Mount St. Helens, Washington, in Abrahams, A.D., ed., Hillslope Processes: Boston, Allen \& Unwin, p. 269-296.

1986, Measurement of debris-flow dynamics at Mount St. Helens, Washington, 1981-1983, in Guidebook to 1986 American Geomorphological Field Group Conference-Mount St. Helens, September 3-7, Cispus Center, Randle, Washington, p. 174.

, 1988, Kinematics of volcanic debris flows, in Proceedings of Kagoshima International Conference on Volcanoes, Kagoshima, Japan, July 19 - 23, 1988: Kagoshima Prefectural Government, p. 613.

, 1989, Hazardous hydrologic consequences of volcanic eruptions and goals for mitigative action-an overview, in Starosolszky, O., and Melder, O.M., eds., Hydrology of Disasters: Proceedings of the World Meteorological Organization Technical Conference, Geneva, November, 1989: London, James and James, p. 220-236. 
- 1992, Rainfall-triggered lahars at Mt. Pinatubo, Philippines, following the June 1991 eruption: Landslide News (Japan Landslide Society), No. 6, p. 6-9.

, 1993, Post-eruption volcaniclastic fan deposition, east flank of Mt. Pinatubo, Philippines [abs.]: Geological Society of America Abstracts with Programs, v. 25, no. 6, p. A395.

, Flow characteristics of large eruption- triggered debris flows at snow-clad volcanoes: constraints for debris-flow models: Journal of Volcanology and Geothermal Research, v. 106, no. 10, p. $1351-1358$.

Pierson, T.C., Costa, J.E., 1984, A rheologic classification of subaerial sediment-water flows, [abs.]: Geological Society of America, Abstracts with Programs, v. 16, no. 6, p. 623.

, 1987, A rheologic classification of subaerial sediment-water flows, in Costa, JE., and Wieczorek, G.F., eds., Debris flows/avalanches: Process, Sedimentology, and Hazard Mitigation: Geological Society of America, Reviews in Engineering Geology, vol. VII, p. 1-12.

Pierson, T.C., Ellen, S.D., and Iverson, R.M., 1992, Spatial and temporal distribution of shallow landsliding during intense rainfall, southeastern Oahu, Hawaii: in Bell, D.H., ed., Landslides (Proceedings of the Sixth International Symposium on Landslides, vol 2): Balkema, Rotterdam, p. 1393-1398.

Pierson, T.C., and Janda, R.J., 1990, A previously unrecognized type of proximal pyroclastic deposit at snow-and ice-covered volcanoes: Geological Society of America Abstracts with Programs, v. 22 , no. 7 , p. A55.

Pierson, T. C., and Janda, R. J., Volcanic mixed avalanches: A distinct eruption-triggered mass-flow process at snow-clad volcanoes: Geological Society of America Bulletin, v. 106, no. 10, p. $1351-1358$.

Pierson, T.C., Scott, K.M., 1983, Downstream dilution of a lahar: Transition from debris flow to hyperconcentrated streamflow, [abs:]: EOS, Transactions of the American Geophysical Union, v. 64 , no. 45, p. 707.

- 1985, Downstream dilution of a lahar: Transition from debris flow to hyperconcentrated streamflow: Water-Resources Research, v. 21, p. 1511-1524.

Pierson, T.C., Janda, R.J., Thouret, J.C., Calvache, M.L., 1986, Initiation, bulking, and channel dynamics of catastrophic debris flows on 13 November 1985, at Nevado del Ruiz, Colombia, [abs.]: EOS, Transactions of the American Geophysical Union, v. 67, no. 16, p. 406.

Pierson, T.C., Janda, R.J., Thouret, J.C., and Borrero, C.A., 1990, Perturbation and melting of snow and ice by the 13 November 1985 eruption of Nevado del Ruiz, Colombia, and consequent mobilization, flow, and deposition of lahars: Journal of Volcanology and Geothermal Research, v. 41, p. $17-66$.

Pierson, T.C., Janda, R.J., Umbal, J.V., and Daag, A.S., 1992, Immediate and long-term hazards from lahars and excess sedimentation in rivers draining Mt. Pinatubo, Philippines: U.S. Geological Survey Water-Resources Investigations Report 92-4039, 35 p. and 1 plate.

Pierson, T.C., and Miller, C.D., 1987, Deadly volcanic debris flows and debris avalanches: Is effective hazard mitigation possible?: Geological Society of America Abstracts with Programs, v. 19, no. 7 , p. 805 . 
Pitlick, J., 1992, Flow resistance under conditions of intense gravel transport: Water Resources Research, v. 28, p. 891-903.

Pitlick, J. and Costa, J.E., 1989, Sediment loads and flow hydraulics during floods: Geological Society of America Abstracts with Programs, v. 21, p. A40.

Pringle, P.T., Cameron, K.A., 1986, Lahar and lahar runout of May 14, 1984, at Mount St. Helens, Washington [abs.]: Proceedings of the 59th Annual Meeting of the Northwest Scientific Association.

Pringle, P. T., Cameron K. A., 1987, Factors affecting the magnitude of May, 1984, and May 1986 lahars at Mount St. Helens, Washington [abs.]: Proceedings of the 60th Annual Meeting of the Northwest Scientific Association, 1 p.

Punongbayan, R.S., de la Crux, E., Gabinete, E., Scott, K.M., Janda, R.J., and Pierson, T.C., 1991, Initial stream channel response to large 1991 volumes of pyroclastic-flow and tephra-fall deposits at Mount Pinatubo, Philippines: EOS, Transactions of the American Geophysical Union, v. 72, no. 44, p. 63.

\section{-R-}

Reid, M.E., and Iverson, R.M., 1989, Topographically induced groundwater flow and elastic effectivestress fields in hillslopes: EOS, Transactions of the American Geophysical Union, v. 70, p. 1098.

-, 1992, Gravity-driven groundwater flow and slope failure potential: 1. Elastic effective-stress model: Water Resources Research, v. 28, no.3, p. 939-950.

Roeloffs, E.A., 1994, An updated numerical simulation of the ground-water system for the Castle Lake debris dam, Mount St. Helens, Washington, and implications for dam stability against heave: U.S. Geological Survey Water-Resources Investigations Report 94-4075, 80 p.

\section{$-\mathbf{S -}$}

Schuster, R.L., and Costa, J.E., 1986, Effect'ś of landslide damming on hydroelectric project: in Proceedings, 5th International Congress, International Association of Engineering Geology, Buenos, Aires, v. 4, A.A.: Boston, Balkema, p. 1295-1307.

1986, A perspective on landslide dams, in Schuster, R.L., ed., Landslide dams: Processes, risk, and mitigation: Geotechnical Publication No. 3, American Society of Civil Engineers, New York, p. 1-20.

, 1990, Tunnel drains for natural dams-A unique underground technology application: in Proceedings, international symposium on unique underground structures, Denver, Colorado, v. 2, Chapter 84 , p. $84-1$ to $84-22$.

Scott, K.M., 1984, Flow transformations and textural variation in lahars at Mount St. Helens, Washington, [abs.]: Geological Society of America Abstracts with Programs, v. 16, no. 6, p. 649 . 
1985, Lahars and flow transformations at Mount St. Helens, Washington, U.S.A., in Proceedings of the International Symposium on Erosion, Debris Flow, and Disaster Prevention, 1985: Tsukuba, Japan, Erosion-Control Engineering Society, p. 209-214.

, 1985, Origin, behavior, and sedimentology of catastrophic lahars at Mount St. Helens, Washington, [abs.]: Geological Society of America Abstracts with Programs, v. 17, no. 7, p. 711.

_ 1988, Origin, behavior, and sedimentology of prehistoric catastrophic lahars at Mount St. Helens, Washington, in Clifton, E.H., ed., Geological Society of America Special Paper 229, p. 23-36.

1988, Origins, behavior, and sedimentology of lahars and lahar-runout flows in the ToutleCowlitz River system: U.S. Geological Survey Professional Paper 1447-A, 74 p.

- 1989, Magnitude and frequency of lahars and lahar-runout flows in the Toutle-Cowlitz River system: U.S. Geological Survey Professional Paper 1447-B, 33 p.

, 1989, Modern and ancient volcaniclastic sedimentation in the Toutle River valley, Mount St. Helens, in Waitt, R.B., Hoblitt, R.P., Criswell, C.W., Scott, K.M., Glicken, H., and Brantley, S.R.: Excusion 2A of the 1989 General Assembly of the International Association for Volcanology and Chemistry of the Earth's Interior: New Mexico Bureau of Mines and Mineral Resources, Memoir 47, p. 54-57.

- 1991, Debris flows and protective measures-Experiences and case histories from Mount St. Helens, Washington: in Proceedings of the International Symposium on Debris Flow and Flood Disaster Protection, Emeishan, Shichuan, Peoples' Republic of China, October 14-18, 1991, vol. A, p. 20-24.

, 1992, Risk analysis of sediment gravity flows at Cascade Range volcanoes-approaches and analogies with alluvial fans, in Jones, M.E., and Laenen, A., eds., Interdisciplinary Approaches in Hydrology and Hydrogeology: American Institute of Hydrology, p. 223-230.

Scott, K.M., and Dinehart, R.L., 1985, Sediment transport and deposit characteristics of hyperconcentrated flow evolved from lahars at Mount St. Helens, Washington: Proceedings of International Workshop on Flow at Hyperconcentrations of Sediment, Beijing, Peoples' Republic of China, Sept. 10-14, 1985, 32 p.

Scott, K.M., and Janda, R.J., 1982, Preliminary map of lahar inundation during the Pine Creek eruptive period in the Toutle-Cowlitz River system, Mount St. Helens, Washington: U.S. Geological Survey Water-Resources Investigation Report 82-4067.

- 1987, Multiple origins of catastrophic lahars at Cascade Range volcanoes-probabilities of precursor events, and hazards in downstream areas [abs.]: Abstract Volume, Hawaii Symposium on How Volcanoes Work, Hilo, January 19-25, 1987, p. 229.

Scott, K.M., Janda, R.)., De la Cruz, E., Gabinete, E., Eto, I., Isada, M., Sexon, M., and Hadley, K.H., in press, Channel and sedimentation responses to large volumes of 1991 volcanic deposits on the east flank of Mount Pinatubo: U.S. Geological Survey Professional Paper.

Scott, K.M., Pringle, P.T., and Vallance, J.W., 1992, Sedimentology, behavior, and hazards of debris flows at Mount Rainier, Washington: U.S. Geological Survey Open-File Report 90-385, 106 p. 
Scott, K.M., and Vallance, J.W., 1993, Hyperconcentrated flows in volcanic settings [abs.]: in International Association of Volcanism and Chemistry of the Earth's Interior, General Assembly, Sept. 25 - Oct. 1, 1993, Canberra, Australia, Abstracts, p. 97.

1994, History of landslides and debris flows at Mount Rainier: U.S. Geological Survey Water Fact Sheet, Open-File Report 93-111, 2 p.

1994, History of landslides and debris flows at Mount Rainier: U.S. Geological Survey Water Fact Sheet, Open-File Report 93-111, 2 p.

-1995, Debris flows, debris avalanches, and flood hazards at and downstream from Mount Rainier, Washington: U.S. Geological Survey Hydrologic Atlas, HA-729, 9 p. and 2 plates.

Shimizu, Yasuyuki, Dinehart, R.L., and Smith, J.D., 1989, Flow modeling in the Toutle River, Washington, in Proceedings of the International Symposium on Sediment Transport Modeling, August 14-18, 1989, New Orleans, Louisiana.

Sikonia, W.G., 1985, Impact on the Columbia River of an outburst of Spirit Lake: U.S. Geological Survey Water-Resources Investigations Report 85-4054, 55 P.

Simon, Andrew, 1991, Channel hydraulics and energy expenditure in channel adjustment: Elk Rock Reach, North Fork Toutle River, Washington [abs.]: Geological Society of America, Abstracts with Programs, v. 23, no. 5, p. A88.

1992, Energy, time, and channel evolution in catastrophically disturbed fluvial systems, in Phillips, J.D., and Renwick, W.H., eds., Geomorphic Systems: Geomorphology, v. 5, p. 345-372.

Simon, Andrew, 1993, Degradation, aggradation, and channel widening: relative roles in channel adjustment and energy expenditure [abs.]: EOS, Transactions of the American Geophysical Union, v. 74, no. 43, p. 151.

Simon, Andrew, and Downs, P.W., in press, An inter-disciplinary approach to evaluation of potential instability in alluvial channels: Geomorphology.

Simon, Andrew, and Thorne, C.R., in press, Dynamic channel adjustment of an unstable coarsegrained stream: Opposing trends of boundary and critical shear stress and the applicability of extremal hypotheses: Earth Surface Processes and Landforms.

Swanson, F.J., Janda, R.J., 1983, Summary of final discussions for symposium on erosion control in volcanic areas, in Ministry of Construction (Japan) Technical Memorandum 1908 of Public Works Research Institute, Proceedings of the Symposium on Erosion Control in Volcanic Areas, July 6-9, 1982, Seattle and Vancouver, Wash., p. 361-371.

Swift, C.H., Kresch, D.L., 1982, Mudflow hazards along the Toutle and Cowlitz Rivers from a hypothetical failure of Spirit Lake blockage: U.S. Geological Survey Water-Resources Investigations Report 82-4125, 10 p.

$-\mathbf{T}-$

Takasaki, K.J., 1993, Ground water in Kilauea Volcano and adjacent areas of Mauna Loa Volcano, Island of Hawaii: U.S. Geological Survey Open-File Report 93-082, 28 p. 
Trabant, D.C., and Brabets, T.P., 1990, Estimates of the snow and ice volumes directly influenced by the 1989-90 eruption of Redoubt Volcano [abs.]: EOS, Transactions of the American Geophysical Union, v. 71, no. 43, p. 1705.

Trabant, D.C., and Meyer, D.F., 1992, Flood generation and destruction of Drift Glacier by the 1989-90 eruption of Redoubt Volcano, Alaska: Annals of Glaciology, v. 16, p. 33-38.

Trabant, D.C., Waitt, R.B., and Major, J.J., 1994, Disruption of Drift Glacier and origin of floods during the 1989-90 eruption of Redoudt Volcano, Alaska: Journal of Volcanology and Geothermal Research, v. 62, p. 369-385.

Turney, G.L., and Klein, J.M., 1982, Surface-water quality data from selected sites in Washington affected by Mount St. Helens eruptions: March 27 - September 30, 1980: U.S. Geological Survey Open-File Report 81-1007, 154 p.

Vaccaro, J.J., 1993, A multilayer aquifer system created by cyclic eruptions of Miocene basalts, Columbia Plateau, Washington, Oregon, and Idaho: Geological Society of America Special Paper.

Vallance, J., in press, Postglacial lahars and potential hazards in the White Salmon River system on the southwest flank of Mount Adams, Washington: U.S. Geological Survey Bulletin.

Voight, Barry, Glicken, Harry, Janda, R.J., Douglass, P.M., 1981, Catastrophic rockslide avalanche of May 18, 1980, in Lipman, P.W., and Mullineaux, D.R., eds., The 1980 Eruptions of Mount St. Helens, Washington: U.S. Geological Survey Professional Paper 1250, p. 347-378.

Voight, Barry, Janda, R.J., Glicken, Harry, Douglass, P.M., Nolan, K.M., 1980: Catastrophic rockslideavalanche of May 18, 1980, Mount St. Helens Volcano, Washington, [abs.]: in Geological Society of America abstracts with programs, v. 12, no. 7, p. 542.

Voight, Barry, Janda, R.J., Glicken, Harry, Douglass, P.M., 1983, Nature and mechanics of the Mount St. Helens rockslide-avalanche of 18 May 1980: Geotechnique, v. 33, p. 243-273.

Voight, Barry, Janda, R. J., Glicken, Harry, Douglass, P. M., 1985, Reply to discussion by Skermer of "Nature and Mechanics of the Mount St. Helens Rockslide Avalanche of 18 May 1980": Geotechnique, v. 35, p. 357-368.

\section{$-W-$}

Waitt, R.B., Gardner, C.A., Pierson, T.C., Major, J.J., and Neal, C.A., in press, Unusual ice diamicts emplaced during 15 December 1989 eruption of Redoubt Volcano, Alaska: Journal of Volcanology and Geothermal Research, v. 62, p. 409-428.

Waitt, R.B., Gardner, C.A., Janda, R.J., Miller, T.P., Major, J.J., Pierson, T.C., Neal, C.A., and Vallance, J.W., 1990, Unusual ice conglomerate emplaced during the 15 December 1989 eruption of Redoubt Volcano, Alaska [abs.]: EOS, Transactions of the American Geophysical Union, v. 71 , no. 43 , p. 1706 . 
Waitt, R.B., Major, J.J., Miller, T.P., and Trabant, D.C., 1990, Effects of eruptions of Redoubt Volcano, Alaska between December 1989 and April 1990 on Drift Glacier [abs.]: EOS, Transactions of the American Geophysical Union, v. 71, no. 43, p. 1705.

Waitt, R.B., Pierson, T.C., MacLeod, N.S., Janda, R.J., Voight, Barry, Holcomb, R.T., 1983, Eruptiontriggered avalanche, flood, and lahar at Mount St. Helens: Effects of winter snowpack: Science, v. 221 , p. $1394-1397$.

Walder, J.S., in press, The nature of depositional contacts between pyroclastic deposits and snow or ice: in Pierson, T.C., eds., U.S. Geological Survey Water-Supply Paper.

Walder, J.S., in press, Comments on "Subglacial floods and the origin of low-relief ice-sheet lobes," by E.M. Shoemaker: Journal of Glaciology.

Walder, J.S., and Costa, J.E., 1993, A model of failure mechanisms of glacier-ice dams: Programme with Abstracts, Third International Geomorphology Conference, Hamilton, Ontario, p. 125.

Walder, J.S., and Driedger, C.L., 1993, Glacier-generated debris flows at Mount Rainier: U.S. Geological Survey Water Fact Sheet, Open-File Report 93-124, 2 p.

__ 1993, Rapid geomorphic change caused outburst floods and debris flows along Tahoma Creek, Mount Rainier, Washington, [abs]: EOS, Transactions of the American Geophysical Union, v. 74 , no. $43, \mathrm{H}-41$, p. 293.

, 1994, Geomorphic change caused by glacial outburst floods and debris flows at Mount Rainier, Washington, with emphasis on Tahoma Creek valley: U.S. Geological Survey Water-Resources Investigations Report 93-4093, 93 p.

_ , in press, Frequent outburst floods from South Tahoma Glacier, Mount Rainier, U.S.A.relation to debris flows, meteorological origin, and implications for subglacial hydrology: Journal of Glaciology.

in press, Rapid geomorphic change caused by glacial outburst floods and debris flows along Tahoma Creek, Mount Rainier, Washington, U.S.A.: Arctic and Alpine Research, vol. 26, no. 4.,

Walder, J.S., and Fowler, A., 1994, Channelized subglacial drainage over a deformable bed: Journal of Glaciology, v. 40, no. 134, p. 1-15.

Waythomas, C.F., Lea, P.D., and Walter, R.C., 1993, Stratigraphic context of Old Crow tephra, Holitna Lowland, interior southwest Alaska: Quaternary Research, v. 40, p. 20-29.

Williams, G.P., and Costa, J.E., 1988, Geomorphic measurements after a flood, in Baker, V.R., Kochel, R.C. and Patton, P.C., eds., Flood Geomorphology: New York, John Wiley \& Sons, Inc., p. 65-77.

Wright, R.L., and Pierson, T.C., 1992, Living with volcanoes: The U.S. Geological Survey's Volcano Hazards Program: U.S. Geological Survey Circular 1073, 57 p.

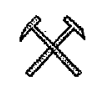

